\title{
AGRICULTURAL WASTE RESIDUES AS POTENTIAL SOURCES OF BIOETHANOL
}

\author{
Chandra Prasad Pokhrel*, Ram Kailash Prasad Yadav* and Shoji Ohga** \\ *Central Department of Botany, Tribhuvan University, Kirtipur, Kathmandu, Nepal. \\ **Department of Forest and Forest Products Sciences, Kyushu University, Fukuoka, Japan.
}

\begin{abstract}
The most common renewable fuel today is ethanol derived from corn grain (starch) and sugar cane (sucrose). It is expected that there will be limits to the supply of these raw materials in the near future as well as these are directly associated with food security. Therefore, lignocellulosic biomass is seen as an attractive alternative feedstock for the future supplies of bioethanol. Technologies are being developed that will allow cost-effective conversion of biomass into fuels and chemicals. About $491 \mathrm{GL}$ of bioethanol might be produced from the wasted crops and their associated lignocellulosic raw materials, about 16 times higher than the current world ethanol production (31 GL).
\end{abstract}

Key words: Bioethanol; Lignocellulosic material; Biofuel; Agricultural residue.

\section{INTRODUCTION}

The term biofuel is referred to as liquid of gaseous fuels for the transport sector that are predominantly produced from biomass. Biofuels are generally considered as offering many priorities, including sustainability, reduction of greenhouse gas emissions, regional development, social structure, agriculture and security of supply (Reijnders, 2006). World wide energy consumption has increased 17 folds in the last century and emissions of $\mathrm{CO}_{2}, \mathrm{SO}_{2}$, and $\mathrm{NO}_{\mathrm{x}}$ from fossil fuel combustion are primarily causes of atmospheric pollution (Ture et al., 1997). Known petroleum reserves are estimated to be depleted in less than 50 years at the present rate of consumption (Sheehan et al., 1998). Growing environmental concerns over the use and depletion of non-renewable fuel sources, together with the increasing price of oil and instabilities in the oil market, have recently stimulated interest in optimizing fermentation process for large scale production of alternative fuels such as ethanol.

Major biofules are biodiesel and ethanol including biohydrogen, biomethanol, biogas, biooil etc. Biodiesel represents an alternative to petroleum-based diesel fuel. It is a mixture of mono-alkyl esters of fatty acids, most often obtained from extracted plant oils and/or collected animal fats. Ethanol is the mostly used liquid biofuel. It is an alcohol and is fermented from sugars, starch or from cellulosic biomass.

Transport sector is major consumer of petroleum fuels such as diesel, gasoline, liquefied petroleum gas (LPG) and compressed natural gas (CNG). This sector is likely to suffer badly because of following reasons: (a) prices of petroleum in global market are rising, (b) petroleum reserves are limited and it is monopoly of some oil-producing countries and rest of the world's heavy dependance on them, and (c) number of vehicles based on petroleum fuels is on increase worldwide (Demirbas, 2007).
In developed countries, there is a growing trend towards employing modern technologies and efficient bio-energy conversion using a range of biofuels, which are becoming costwise competitive with fossil fuels (Demirbas, 2000). Advantages of bio-fules are: (a) they are easily available from common biomass sources, (b) they are better represented in the $\mathrm{CO}_{2}$ cycle on combustion; (c) they are more economical than conventional fuels, and (d) they are biodegradable and contribute to sustainability (Puppan, 2002).

Biomass has been recognized as a major world renewable energy source to supplement declining fossil fuel resources (Ozeimen and Karaosmanoglu, 2005; Jefferson, 2006). Biomass appears to be an attractive feedstock for three main regions. First, it is a renewable resource that could be sustainably developed in the future. Second, it appears to have formidably positive environmental properties resulting in no net release of carbon dioxide $\left(\mathrm{CO}_{2}\right)$ and very low sulfur content. Third, it appears to have significant economic potential provided that fossil fuel prices increase in the future (Cadenas and Cabezudo, 1998). Many research programs recently focus on the development of concepts such as renewable resources, sustainable development, green energy, climate change, eco-friendly process, etc. in the transportation sector. This paper is mainly focused on reviewing biomass based transportation fuel such as ethanol, its importance, production technology (biorefinery), sustainability and major potential feedstocks such as crop wastes and agricultural residues for its production.

\section{Global scenario}

Renewable resources are more evenly distributed than fossil and nuclear resources, and energy flow from renewable resources are more than three orders of magnitude higher than current global energy use. Today's energy system is unsus-

Author for Correspondence: Chandra Prasad Pokhrel, Central Department of Botany, Tribhuvan University, Kirtipur, Kathmandu, Nepal. Email: chandraprkh@yahoo.com 
tainable because of equity issue as well as environmental, economic, and geopolitical concern that have implications far into the future (UNDP, 2000). The world ethanol production in 2001 was 31 GL (Berg, 2001). High production of ethanol is recorded in Brazil and US, which account for about $62 \%$ of world production. The major feedstock for ethanol in Brazil is sugarcane, while corn grain is the main feedstock for ethanol in the US. Another potential resource of ethanol is lignocellulosic biomass (Kim and Dale, 2004). According to International Energy Agency (IEA, 2004), scenarios developed for the USA and the EU indicate that near-term targets of up to $6 \%$ displacement of petroleum fuels with bio-fuels appear feasible using conventional biofuels, given available cropland. A 5\% displacement of gasoline in the EU requires about $5 \%$ of available cropland to produce ethanol while in the USA about $8 \%$ is required. A $5 \%$ displacement of diesel requires $13 \%$ of USA cropland, and $15 \%$ in the EU.

\section{Bioethanol}

Ethanol derived from biomass, one of the modern forms of biomass energy, has the potential to be sustainable transportation fuel, as well as a fuel oxygenated that can replace gasoline (Kim and Dale, 2004). Bioethanol is a petrol additive/substitute. Bioethanol is a fuel derived from renewable sources of feedstock; typically plants such as wheat, sugar beet, corn, straw, and wood. It is possible that wood, straw and even household wastes may be economically converted to bioethanol. Carbohydrates (hemicellulose and cellulose) in plant material can be converted to sugar by hydrolysis process. Fermentation is a process in which alcohol is produced anaerobically by the action of microorganism (usually yeast) and the alcohol produced are mostly ethanol. The value of any particular type of biomass as feedstock for fermentation depends on the ease with which it can be converted to alcohol.

Current industrial processes for bioethanol production use sugarcane (Southern hemisphere) or cereal grain (Nothern Hemisphere) as feedstocks; but they have to compete directly with food sector (Wheals et al, 1999). Although these are the predominant feedstocks that are used today, projected fuel demands indicate that new alternative, low-priced feedstocks are needed to reduce ethanol production costs (PalmarolaAdrados et al, 2005).

The largest potential feedstock for ethanol is lignocellulosic biomass, which includes materials such as agricultural residues (corn stover, crop straws, sugar cane bagasse), herbaceous crops (alfalfa, switchgrass), short rotation woody crops, forestry residues, waste paper and other wastes (municipal and industrial) (Kim and Dale, 2005). Bioethanol production from these feedstocks could be an attractive alternative for disposal of these residues (Wymam, 2001). Importantly, lignocellulosic feedstocks do not interfere with food security. Moreover, bioethanol is very important for both rural and urban areas in terms of energy security reason, environmental concern, employment opportunities, agricultural development, foreign exchange saving, socioeconomic issues etc.

\section{Processing technology}

Unlike corn grain where the major carbohydrate is starch, li- gnocellulosic biomass is composed of cellulose (40-50\%), hemicellulose (25-35\%) and lignin (15-20\%). Starch processing is a fairly mature technology utilizing enzymatic liquefaction and saccharifaction, which produces a relatively clean glucose stream that is then fermented to ethanol by Saccharomyces yeasts. Recent advances in starch processing have improved the economics and efficiency of the process (Gray et al., 2006). One example has been the development of low $\mathrm{pH}$ Ü-amylases that simplify the process and reduce chemical cost as well as improving ethanol yield (Richardson et al., 2002). The other major advance is the development of enzymes that function on raw, uncooked starch, thereby improving overall process economics (Shetty et al., 2005; Bhargava et al, 2005). The compactness and complexity of lignocellulose makes it much more difficult than starch to enzymatically degrade to fermentable sugar. Hence, the cost of producing a gallon of ethanol from this is higher than production from starch (Wyman, 2003). In order to make it cost competitive with grainderived ethanol, the enzymes used for biomass hydrolysis must become more efficient and far less expensive. In addition, the presence of non glucose sugars in the feedstock complicates the fermentation process because conversion of pentose sugars into ethanol is less efficient than conversion of the hexose sugars (Gray et al, 2006).

In this review, we focus on the progress made over the past several years in the development of processes to more effectively and efficiently convert lignocellulosic materials into ethanol. There are three major steps in the conversion process (Figure 1): first, thermochemical pretreatment - a preprocessing step that improves enzymes access to the cellulose; second, enzymatic saccharification - use of cellulases and on some occasions hemicellulases; and thirdly, fermentation of the released sugars by specialized organisms (Gray et al., 2006). Cellulases from aerobic fungus Trichoderma reesei have been the focus of research for the last 50 years and are most commonly used source of celluloses in lab and pilot-scale bioethanol production (Gray et al., 2006). A greater than 10fold cost reduction for $T$. reesei cellulases was recently developed (Geer, 2005).

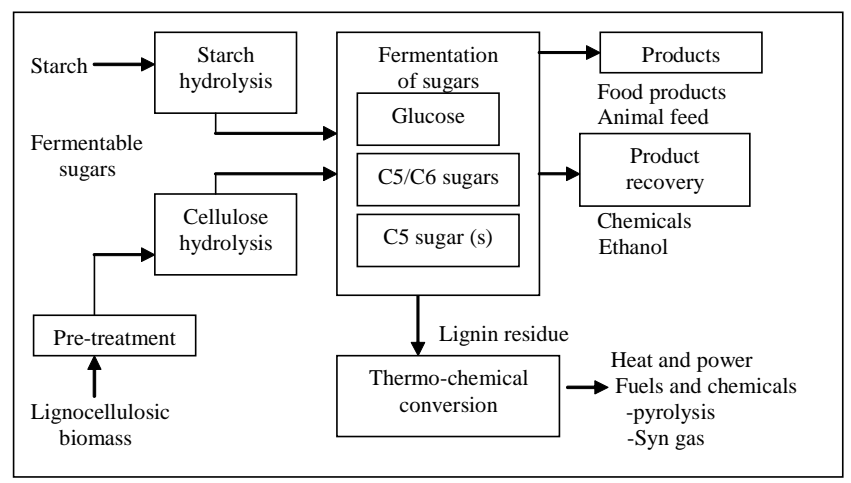

Figure1: Schematic diagram showing biomass and starch processing in a biorefinery (Gray et al., 2006).

\section{Cost of biofuel}

Production cost of biofuels vary considerably and is dependent on the price of raw materials, the method of production, the extent of refining undertaken, and the supplementary uti- 
Table 1: Cost of biofuels (Jungmeier et al., 2005)

\begin{tabular}{|c|c|c|c|c|}
\hline \multirow[t]{2}{*}{ Biofuel } & \multicolumn{4}{|c|}{ Cost at filling station $\left(€_{2004} / 1000 \mathrm{~L}\right)$} \\
\hline & Feedstock & Low & Best estimate & High \\
\hline \multicolumn{5}{|c|}{ (a) Costs of biofuels produced using current technology } \\
\hline Suga & & 875 & 1265 & 1855 \\
\hline Starc & & 809 & 1173 & 1572 \\
\hline Lig & sic crops & 1148 & 1448 & 2435 \\
\hline Ligi & sic residues & 1052 & 1316 & 2232 \\
\hline Bra & arcane & 117 & 294 & 351 \\
\hline \multicolumn{5}{|c|}{ Biodiesel } \\
\hline Oil s & & 755 & 945 & 1092 \\
\hline Use & & 354 & 454 & 545 \\
\hline \multicolumn{5}{|c|}{ (b) Cost of biofuel using future technology ( post-2010) } \\
\hline Suga & & 671 & 954 & 1432 \\
\hline Starc & & 653 & 963 & 1287 \\
\hline LigI & sic crops & 699 & 884 & 1469 \\
\hline LigI & sic residues & 638 & 802 & 1358 \\
\hline \multicolumn{5}{|c|}{ Brazilian sugarcane } \\
\hline \multicolumn{5}{|c|}{ Biodiesel } \\
\hline Oil s & & 753 & 888 & 1068 \\
\hline Use & & 317 & 395 & 504 \\
\hline
\end{tabular}

Table 2: Quantities of wasted crops and lignocellulosic biomass potentially available for bioethanol (Kim and Dale, 2004)

\begin{tabular}{lcccccccc}
\hline & Africa & Asia & Europe & $\begin{array}{c}\text { North } \\
\text { America }\end{array}$ & $\begin{array}{c}\text { Central } \\
\text { America }\end{array}$ & Oceania & $\begin{array}{c}\text { South } \\
\text { America }\end{array}$ & $\begin{array}{c}\text { Subtotal } \\
\text { Wasted crop (Tg) }\end{array}$ \\
& & & & & & & & \\
Corn & 3.12 & 9.82 & 1.57 & 0.30 & 1.74 & 0.01 & 4.13 & 20.70 \\
Barley & 0.17 & 1.23 & 2.01 & 0.01 & 0.01 & 0.19 & 0.04 & 3.66 \\
Oat & 0.004 & 0.06 & 0.43 & 0.01 & 0.001 & 0.001 & 0.05 & 0.55 \\
Rice & 1.08 & 21.86 & 0.02 & 0.96 & 0.08 & 0.02 & 1.41 & 25.44 \\
Wheat & 0.83 & 10.28 & 4.09 & 0.02 & 0.24 & 0.82 & 0.91 & 17.20 \\
Sorghum & 2.27 & 0.54 & 0.004 & 0.00 & 0.13 & 0.001 & 0.18 & 3.12 \\
Sugar cane & 0.46 & 1.64 & 0.00 & 0.00 & 0.36 & 0.00 & 0.74 & 3.20 \\
Subtotal & 7.94 & 45.43 & 8.13 & 1.30 & 2.56 & 1.05 & 7.45 & 73.86 \\
\hline Lignocellulosic biomass (Tg) & & & & & & & \\
\hline Corn stover & 0.00 & 33.90 & 28.61 & 133.66 & 0.00 & 0.24 & 7.20 & 203.62 \\
Barley straw & 0.00 & 1.97 & 44.24 & 9.85 & 0.16 & 1.93 & 0.29 & 58.45 \\
Oat straw & 0.00 & 0.27 & 6.83 & 2.80 & 0.03 & 0.47 & 0.21 & 10.62 \\
Rice straw & 20.93 & 667.59 & 3.92 & 10.95 & 2.77 & 1.68 & 23.51 & 731.34 \\
Wheat straw & 5.34 & 145.20 & 132.59 & 50.05 & 2.79 & 8.57 & 9.80 & 354.35 \\
Sorghum straw & 0.00 & 0.00 & 0.35 & 6.97 & 1.16 & 0.32 & 1.52 & 10.32 \\
Bagasse & 11.73 & 74.88 & 0.01 & 4.62 & 19.23 & 6.49 & 63.77 & 180.73 \\
Subtotal & 38.00 & 923.82 & 216.56 & 218.90 & 26.14 & 19.70 & 106.30 & 1549.42 \\
\hline
\end{tabular}

lization of by-products and wastes. The costs are also highly variable depending on the various combination of feedstock and country of production. Since the price of feedstock contributes more than 55\% to the production cost, inexpensive feedstocks such as lignocellulosic biomass and agri-food wastes are being considered to make bioethanol competitive in the open market (Lichts, 2004).

The European biofule cost estimates from Jungmeier et al., (2005) are shown in Table 1. It reports a range of cost estimates including the lowest, the most likely values (best estimates) and the highest value from studies including estimates of the future costs (post-2010), as being significantly lower. By using current production technology, the cheapest bioethanol production in Europe and Brazil comes from starch crop and sugarcane respectively. The table also shows that biodiesel is cheapest when produced from waste oils and fats.

\section{Potential Lignocellulosic residues}

To avoid conflicts between food use and industrial use of crops, only wasted crops are assumed to be available for producing ethanol. Wasted crops are defined as crops lost during the year at all stages between the farm and households level during handling, storage and transport. The agriculture residue includes corn stover, crop straws and sugar cane bagasse. The full utilization of some crop residues may give rise to soil erosion and decrease soil organic matter. Therefore, a $60 \%$ ground cover by residues, instead of $30 \%$, is recommended due to uncertainties of local situation (Kim and Dale, 2004). Most wasted biomass comes from rice, corn, and wheat, as shown in Table 2. Asia has $45 \mathrm{Tg}$ of wasted biomass.

About 491 GL of bioethanol might be produced from the wasted crops and their associated lignocellulosic raw materials, about 16 times higher than the current world ethanol pro- 
Table 3: Potential bioethanol production (Kim and Dale, 2004)

\begin{tabular}{lcccccccc}
\hline & Africa & Asia & Europe & $\begin{array}{c}\text { North } \\
\text { America }\end{array}$ & $\begin{array}{c}\text { Central } \\
\text { America }\end{array}$ & Oceania & $\begin{array}{c}\text { South } \\
\text { America }\end{array}$ & $\begin{array}{c}\text { Subtotal } \\
\text { From wasted crop }(G L)\end{array}$ \\
Corn & 2.17 & 6.82 & 1.09 & 0.21 & 1.21 & 0.01 & 2.87 & 14.4 \\
Barley & 0.12 & 0.83 & 1.35 & 0.005 & 0.01 & 0.13 & 0.03 & 2.46 \\
Oat & 0.002 & 0.04 & 0.30 & 0.01 & 0.0004 & 0.001 & 0.03 & 0.38 \\
Rice & 0.71 & 14.4 & 0.02 & 0.63 & 0.05 & 0.02 & 0.93 & 16.8 \\
Wheat & 0.55 & 6.78 & 2.70 & 0.02 & 0.16 & 0.54 & 0.60 & 11.3 \\
Sorghum & 1.55 & 0.37 & 0.003 & - & 0.09 & 0.0004 & 0.12 & 2.14 \\
Sugar cane & 0.23 & 0.82 & - & - & 0.18 & 0.0001 & 0.37 & 1.59 \\
Subtotal (A) & 5.33 & 30.1 & 5.45 & 0.87 & 1.70 & 0.70 & 4.95 & 49.1 \\
\hline From Lignocellulosic & biomass $(G L)$ & & & & & & \\
\hline Corn stover & - & 9.75 & 8.23 & 38.4 & - & 0.07 & 2.07 & 58.6 \\
Barley straw & - & 0.61 & 13.7 & 3.06 & 0.05 & 0.60 & 0.09 & 18.1 \\
Oat straw & - & 0.07 & 1.79 & 0.73 & 0.009 & 0.12 & 0.06 & 2.78 \\
Rice straw & 5.86 & 186.8 & 1.10 & 3.06 & 0.77 & 0.47 & 6.58 & 204.6 \\
Wheat straw & 1.57 & 42.6 & 38.9 & 14.7 & 0.82 & 2.51 & 2.87 & 103.8 \\
Sorghum straw & - & - & 0.10 & 1.89 & 0.31 & 0.09 & 0.41 & 2.79 \\
Bagasse & 3.33 & 21.3 & 0.004 & 1.31 & 5.46 & 1.84 & 18.1 & 51.3 \\
Subtotal (B) & 10.8 & 261.0 & 63.8 & 63.3 & 7.42 & 5.70 & 30.2 & 442.0 \\
Total (AB) & 16.1 & 291.1 & 69.2 & 64.0 & 9.12 & 6.39 & 35.1 & 491.1 \\
\hline
\end{tabular}

duction (31 GL). Crop residues are responsible for $90 \%$ of the total potential bioethanol production. The potential bioethanol production can replace 353 GL of gasoline, which is equivalent to $32 \%$ of total world wide gasoling consumption, when bioethanol is used in E85 for mid sized passenger veichel ( Kim and Dale, 2004). Asia, which can produced 291 GL of bioethanol, is the largest potential producer. Rice straw (187 GL) is the most available feedstock in Asia. The next largest feedstocks in Asia are wheat straw (42.6 GL) and sugar can bagasse (21.3 GL). The next largest potential producer of bioethanol in the world is Europe (69.2 GL), in which most bioethanol comes from wheat straw. Corn stover (38.4 GL) is the main feedstock for bioethanol in North America. These quantities are shown in Table 3.

\section{CONCLUSION}

The term biofuel is referred to as liquid form of gaseous fuel for the transport sector that is predominantly produced from biomass. Bioethanol is a petrol additive/substitute with marvelous benefits. It is very important for both rural and urban areas in terms of energy security, environmental concern, employment opportunities, agricultural development, foreign exchange saving, socioeconomic issues etc. The most common renewable fuel today is ethanol derived from corn grain (starch) and sugar cane (sucrose). Lignocellulosic biomass is seen as an attractive feedstock for the future supplies of bioethanol which do not interfere with food security.

Efficient and economic technology is being advanced day by day for considerable production of bioethanol. These technologies include low-cost thermochemical pretreatment, highly effective cellulases and hemicellulases and efficient and robust fermentative microorganisms. Significant progress has been made in the past several years in all aspects of lignocellulosic conversion to ethanol.
Biomass availability is a primary factor for bioethanol production. Rice straw is potentially the most favorable feedstock, and the next most favorable raw materials are wheat straw, corn stover and sugar cane bagasse in terms of quantity of biomass available. These four feedstocks can produce significant amount of bioethanol. The most favorable region is Asia, and of course also Nepal, which can produce largest amount of bioethanol because of biomass availability.

\section{REFRENCES}

Berg, C. 2001. World Ethanol Production. The Distallery and Bioethanol Network. Available at http://www.distill.com/world ethanol production.htm.

Bhargav, S., Frisner, H., Bisgard-Frantzen, H. and Tams, J. W. 2005. (Novoenzymes North America IU, NovoenzymeA/S) Productional of ethanol from enzymatically hydrolyzed. Patent 2005113785.

Cadenas, A., and Cabezudo, S. 1998. Biofuels as sustainable technologies: perspectives for less developed countries. Technology Forecast Social Change. 58:83-103.

Demirbas, A. 2000. Biomass resources for energy and chemical industry. Energy Education Science and Technology. 5:21-45.

Demirbas, A. 2007. Progress and recent trends in biofuels. Progress in Energy and combustion science. 33:1-18.

Geer, D. 2005. Spinning straw into fuel. Biocycle. 46:61-65.

Gray, K. A., Zhao, L. and Emptage, M. 2006. Bioethanol. Current Opinion in Chemical Biology.10:141-146.

IEA (International Energy Agency) 2004. Biofuels for transport: An international perspective. Available at www.iea.org

Jefferson, M. 2006. Sustainable energy development: performance and prospects. Renewable Energy. 31: 571-582.

Jungmeier, G., Koenighofer, K., Varela, M., and Lago, C. 2005. Economic and Environmental Performance of Biofuel. Work Package 2, VIEWLS Project. Clear Views on Clean Fuels: Data Potential, Scenarios, Markets and Trade of Biofuels, EC Project NNE5-2001-00619. 
Kim, S. and Dale, B. E. 2004. Life cycle assessment of various cropping systems utilized for producing biofuels: Bioethanol and biodiesel. Biomass and Bioenergy. 26: 426-439.

Kim, S. and Dale, B. E. 2005. Global Potential bioethanol production from wasted crops and crop residues. Biomass and Bioenergy. 29:361-375.

Lichts, F. O. 2004. Ethanol Production Costs: A World Wide Survey. Special Report No. 132.

Ozeimen, D. and Karaosmanoglu, F. 2005. Production and characterization of bio-oil and biochar from rapeseed cake. Renewable Energy. 29:779-787.

Palmarola-Adrados, B., Choteborska, P., Galbe, M., and Zacchi, G. 2005. Ethanol production from non-starch carbohaydrates of wheat bran. Bioresource Technology. 96:843-850.

Puppan, D. 2002. Environmental evaluation of biofuels. Period Polytech Ser Soc Man Science. 10:95-116.

Reijnders L. 2006. Conditions for sustainability of biomass based fuel use. Energy Policy. 34: 863-876.

Richardson, T. H., Tan, X., Frey, G., Callen, W., Cabell, M., Lam, D., Micomber, J., Short, J. B., Roberston, D. E., and Miller, C. 2002. A novel, high performance enzyme for starch liquefaction. Discov- ery and optimization of low $\mathrm{pH}$, thermostable alpha-amylase. Journal of Biological Chemistry. 277:26501-26507.

Sheehan, J., Cambreco, V., Duffield, J., Garboski, M., and Shapouri, H. 1998. An overview of biodiesel and petroleum diesel life cycles. A report by US Department of Agriculture and Energy. pp. 1-35.

Shetty, J. K., Lantero, O. J., and Dunn-Coleman, N. 2005. Technological advance in ethanol production. International Sugar Journal. 107:605-608.

Ture, S., Uzun, D., and Ture, I. E. 1997. The potential use of sweet sorghum as a non- polluting source of energy. Energy. 22:17-9.

UNDP (United Nnations Development Programme) 2000. Energy and the challenge of sustainability. World Energy Assessments.

Wheals, A. E., Basso, L. C., Alves, D. M. G., and Amorim, H. V. 1999. Fuel ethanol after 25 years. Trends Biotechnology. 17:482-487.

Wyman, C. E. 2001. Twenty years of trials, tribulations, and research progress in bioethanol technology. Appl Biochemical and Biotechnology. 91: 2-12.

Wyman, C. E. 2003. Potential synergies and challenges in refining cellulosic biomass to fuels, chemicals and power. Biotechnological Progress. 19:245-262. 